\title{
КОРЕЛЯЦІЙНІ ЗВ'ЯЗКИ МІЖ ОРЕКСИГЕННИМИ ТА АНОРЕКСИГЕННИМИ ГОРМОНАМИ ПРИ МЕТАБОЛІЧНОМУ СИНДРОМІ
}

Кореляційні зв'язки між орексигенними та анорексигенними гормонами при метаболічному синдромі

\section{І. Я. Дзюбановський, А. М. Продан, Л. М. Романюк}

Тернопільський національний медичний університет імені І. Я. Горбачевського МОЗ України

Резюме. Метаболічний синдром відіграє провідну роль у розвитку серцево-судинних та ендокринних захворювань. До теперішнього часу проводяться дискусії про роль тих чи інших гормонів у розвитку та перебігу даного захворювання. Адже розуміння патофрізіологічних особливостей дасть змогу адекватно коригувати прояви метаболічного синдрому на різних його етапах.

Мета дослідження - вивчити кореляційний зв'язок між рівнями греліну, лептину, інсуліну та основними метаболічними показниками у пацієнтів з ожирінням різного ступеня.

Матеріали і методи. Обстежено 44 пацієнти (59,10 \% - жінок та 40,90 \% - чоловіків) віком від 31 до 79 років з індексом маси тіла >30 кг/м² (основна група) та 12 пацієнтів (66,67 \% - жінок та 33,34 \% - чоловіків) віком від 25 до 67 років, з індексом маси тіла <25 кг/M², що склали контрольну групу. Рівні глікованого гемоглобіну (HbA1c), глікемії, а також загального холестерину, ліпопротеїнів низької (ЛПНЩ) та високої щільності (ЛПВЩ), тригліцеридів, аланінамінотрансфрерази (АлАT), аспартатамінотрансфрерази (АсAT), креатиніну в плазмі крові вимірювали за допомогою комерційних наборів (Roche Diagnostics) за допомогою Hitachi automatic analyzer. Визначення сироваткових рівнів лептину та греліну здійснювали за допомогою Leptin ELISA (LDN Labor Diagnostika Nord GmbH\&Co.KG, Germany) ma Human Ghrelin ELISA Kit (Thermo Fisher Scientific, USA) на аналізаторі Multiskan FC. Cmamucтичну оброку даних проводили із використанням варіаційного та кореляційного аналізу.

Результати. Проведений кореляційний аналіз у групах пацієнтів із різним ступенем ожиріння дозволив встановити залежність між IMT та рівнем лептину $(r=+0,99)$, греліну $(r=-0,86)$, HbA1c $(r=+0,60)$, холестерину $(r=+0,99)$, ЛПНЩ $(r=+0,98)$, ЛПВЩ $(r=-0,99)$, коефріцієнтом атерогенності $(r=+0,96)$, інсуліну $(r=+1,00)$, глікемією $(r=+0,84)$. Порівнявши показники концентрації лептину та греліну при різних ступенях ожиріння, встановлено сильний зворотний зв'язок ( $r=-0,92)$, коли із зростанням IMT та концентрації лептину си-
Correlations between orexigene and anorexigene hormones in metabolic syndrome

I. Ya. Dziubanovskyi, A. M. Prodan, L. M. Romanyuk

I. Horbachevsky Ternopil National Medical University

e-mail: prodan@tdmu.edu.ua

Summary. Metabolic syndrome plays a leading role in the development of cardiovascular and endocrine diseases. To date, there are discussions about the role of certain hormones in the development and course of this disease. After all, understanding the pathophysiological features will allow to adequately correct the manifestations of metabolic syndrome at different stages.

The aim of the study - to investigate the correlation between the levels of ghrelin, leptin, insulin and the main metabolic parameters in obese patients of varying degrees.

Materials and Methods. There were examined 44 patients (59.10\% - women and $40.90 \%$ - men) aged 31 79 with a body mass index $>30 \mathrm{~kg} / \mathrm{m}^{2}$ (main group) and 12 patients (66.67\% - women and $33.34 \%$ - men) aged 25-67, with a body mass index $<25 \mathrm{~kg} / \mathrm{m}^{2}$, which made up the control group. Levels of glycated hemoglobin (HbA1c), glycemia, as well as total cholesterol, low and high density lipoproteins, triglycerides, alanine aminotransferase, aspartate aminotransferase, and plasma creatinine were measured by Hitachi automatic analyzer. Serum leptin and ghrelin levels were determined using Leptin ELISA (LDN Labor Diagnostika Nord GmbH \& Co.KG, Germany) and Human Ghrelin ELISA Kit (Thermo Fisher Scientific, USA) on a Multiskan FC analyzer. Statistical processing of data was performed using variation and correlation analysis.

Results. Correlation analysis in groups of patients with varying degrees of obesity revealed a relationship between $B M I$ and the level of leptin $(r=+0.99)$, ghrelin $(r=-0.86)$, HbA1c $(r=+0.60)$, cholesterol $(r=+0.99)$, LDL $(r=+0.98)$, $H D L(r=-0.99)$, atherogenic factor $(r=+0.96)$, insulin ( $r$ $=+1.00$ ), glycemia $r=+0.84$ ). A comparison of leptin and ghrelin concentrations at different degrees of obesity showed strong feedback ( $r=-0.92)$, when serum ghrelin levels decreased with increasing BMI and leptin concentration. At the same time, after analyzing the relationship between leptin and insulin, a strong direct relationship was found ( $r=$ +0.99 ), which increased the concentration of both indicators with increasing BMI. 
роватковий рівень греліну знижувався. Разом з тим, проаналізувавши взаємозалежність концентрації лептину й інсуліну, встановлено сильний прямий зв'язок $(r=+0,99)$, за якого відбувалося зростання концентрації обох показників із збільшенням індексу маси тіла (IMT).

Висновки. Результати проведеного аналізу підтвердили наявність дисбалансу орексигенних та анорексигенних гормонів у пацієнтів з ожирінням, при цьому відмічено прогресивне зростання концентрації лептину, інсуліну та зниження рівня греліну зі збільшенням ступеня ожиріння, що підтверджено відповідними кореляційними зв'язками.

Ключові слова: метаболічний синдром; грелін; лептин; інсулін.

\section{ВСТУП}

Сьогодні метаболічний синдром - це всесвітня пандемія, що налічує більш як 2,1 млрд хворих осіб, та без сумніву асоціюється з ризиком розвитку численних супутніх захворювань, таких, як серцевосудинні, діабет 2 типу та багато інших [3, 9].

Підвищений рівень вільних жирних кислот, запальних цитокінів та ліпідних проміжних продуктів у тканинах сприяє порушенню сигналізації інсуліну та інсулінорезистентному стану, що $є$ у багатьох пацієнтів із ожирінням $[6,10]$. Ця сукупність метаболічних змін є одним із кількох патофрізіологічних механізмів, що лежать в основі дисліпідемії ожиріння (підвищений рівень тригліцеридів плазми натще та ліпопротеїнів низької щільності (ЛПНЩ) та низький рівень холестерину ліпопротеїнів високої щільності (ЛПВщ)) та цукрового діабету 2 типу.

Адипоцити синтезують адипокіни та гормони, на швидкість секреції та вплив яких впливає розподіл та кількість наявної жирової тканини. За останні два десятиліття багато досліджень показує, що пептидний гормон лептин, отриманий з адипоцитів, відіграє важливу роль у зв'язку з ожирінням, запаленням, метаболічним синдромом та серцево-судинними захворюваннями [8].

У нормі інсулін підтримує належне накопичення та використання енергії, лептин зменшує постійне споживання енергії. Обоє вони відіграють ключову роль у центральному регулюванні витрат енергії та гомеостазі глюкози [11]. Встановлено, що гіперлептинемія $є$ рушійною силою ожиріння та пов'язаного з ним метаболічного синдрому [12]. Також підвищені рівні лептину та хронічна гіперактивність симпатичної нервової системи, наявні у деяких пацієнтів 3 ожирінням, частково пояснюють множинні патофрізіологічні процеси, включаючи високий кров'яний тиск [5].

Грелін, у свою чергу, знижує симпатичну активність і пригнічувально діє на центральну нервову систему. Завдяки взаємодії греліну та лептину гіпоталамус може регулювати відчуття голоду та ситос-
Conclusions. The analysis confirmed the presence of an imbalance of orexigenic and anorexigenic hormones in obese patients, with a progressive increase in leptin, insulin and a decrease in ghrelin levels with increasing obesity, as evidenced by the corresponding correlations.

Key words: metabolic syndrome; ghrelin; leptin; insulin.

ті, що призводить до гомеостазу енергії, а дисбаланс та порушення регуляції цих гормонів можуть мати різкий вплив на енергетичний гомеостаз організму та розвиток цукрового діабету та серцево-судинних захворювань [1, 4, 7].

Метою дослідження було вивчити кореляційний зв'язок між рівнями греліну, лептину, інсуліну та основними метаболічними показниками у пацієнтів з ожирінням різного ступеня.

\section{МАТЕРІАЛИ І МЕТОДИ}

Обстежено 44пацієнти (59,10\%-жінокта 40,90\%чоловіків) віком від 31 до 79 років з індексом маси тіла $>30$ кг/м² (основна група) та 12 пацієнтів (66,67 \% жінок та 33,34 \% - чоловіків) віком від 25 до 67 років, з індексом маси тіла $<25$ кг/м², що склали контрольну групу. Отримано інфрормовану згоду на запропоноване обстеження у всіх хворих.

Клінічні дані (стать, вік, зріст, маса тіла, індекс маси тіла (IMT), об'єм талії та артеріальний тиск сидячи) були проаналізовані. Зразки крові, які брали для дослідження, були отримані після того, як пацієнти постили за ніч. Рівні глікованого гемоглобіну (HbA1c), глікемії, а також загального холестерину, ліпопротеїнів низької та високої щільності, тригліцеридів, аланінамінотрансорерази (АлАТ), аспартатамінотрансорерази (АсАТ), креатиніну в плазмі крові вимірювали за допомогою комерційних наборів (Roche Diagnostics) за допомогою Hitachi automatic analyzer. Індекс інсулінорезистентності розраховували за методикою Caro, як величину відношення рівня глюкози до інсуліну, виміряного в обстежуваних натще [2].

Артеріальний тиск (АТ) вимірювали тричі на правій руці в положенні сидячи протягом 10 хв і вважали збільшеним, якщо він перевищував рівень 139/89 мм рт. ст. Для визначення характеру розподілу жиру використовували показник відношення об'єму талії до об'єму стегон (ОТ/ОС), при його значенні більше 1 констатували абдомінальний тип ожиріння.
Вісник медичних і біологічних досліджень Bulletin of Medical and Biological Research
$4(10), 2021$ 
Для вимірювання рівня лептину та греліну в сироватці крові 5 мл крові збирали у вакуумні пробірки. Після цього зразки тримали 30 хв за кімнатної температури, а потім центрифугували при 1670 g протягом 10 хв. Ізольовані зразки сироватки зберігали в морозильній камері при $-20{ }^{\circ} \mathrm{C}$. Визначення сироваткових рівнів лептину та греліну здійснювали за допомогою Leptin ELISA (LDN Labor Diagnostika Nord GmbH\&Co.KG, Germany) ta Human Ghrelin ELISA Kit (Thermo Fisher Scientific, USA) на аналізаторі Multiskan FC (версія програми Skanlt Software 4.1 for Microplate Readers RE, ver. 4.1.0.43) при довжині хвилі 620 нм.

Статистичну оброку даних проводили із використанням варіаційного та кореляційного аналізу. Обчислення результатів дослідження проводилось на основі застосування стандартних програмних продуктів обробки інорормації Statistica.

\section{РЕЗУЛЬТАТИ Й ОБГОВОРЕННЯ}

Порівняльну оцінку метаболічних порушень у групі з ожирінням та контрольною групою наведено в таблиці 1.

Результати аналізу даних таблиці 1 показали наявність суттєвої достовірної різниці між двома групами за такими показниками: IMT, САТ, інсулін, індекс Caro, грелін загальний, лептин, АлАТ та АсAT, що вказує на значний дисбаланс обмінних процесів у пацієнтів із метаболічним синдромом. Несуттєвою виявилась різниця у пацієнтів з ожирінням та контрольною групою за такими параметрами: глікемія, HbA1c, холестерин, лПнЩ, ЛПВЩ, тригліцериди, коефіцієнт атерогенності та креатинін, що може свідчити про менш виражені зміни цих показників у двох групах.

У таблиці 2 продемонстровано прогресивне збільшення концентрації лептину в сироватці крові залежно від ступеня ожиріння. Необхідно вважати, що при ожирінні, вже навіть I ст., має місце резистентність до лептину, можливо на етапі його транспортування через гематоенцесралічний бар'єр, а в певних випадках на пострецепторному рівні внаслідок ймовірної генетичної «поломки».

Проведений кореляційний аналіз у групах пацієнтів із різним ступенем ожиріння дозволив встановити залежність між IMT та рівнем лептину $(r=+0,99)$, греліну $(r=-0,86)$, HbA1c $(r=+0,60)$, холестерину $(r=+0,99)$, ЛПНЩ $(r=+0,98)$, ЛПВЩ $(r=-0,99)$, коефріцієнтом атерогенності $(r=+0,96)$, інсуліну $(r=+1,00)$, глікемією $(r=+0,84)$.

Порівнявши показники концентрації лептину та греліну при різних ступенях ожиріння, встановлено сильний зворотний зв'язок $(r=-0,92)$, коли із зростанням IMT та концентрації лептину сироватковий рівень греліну знижувався.

Разом з тим, проаналізувавши взаємозалежність концентрації лептину й інсуліну, встановлено сильний прямий зв'язок $(r=+0,99)$, за якого відбувалося зростання концентрації обох показників із збільшенням IMT. Надлишок лептину суттєво підсилює прояви інсулінорезистетності у пацієнтів, за результатами визначеного рівня інсуліну та індексу Caro.

Концентрація інсуліну в пацієнтів достовірно вища навіть при I ст. ожиріння, порівняно з контрольною групою $(p=0,009)$, і наростала зі збільшенням маси жирової тканини. Вираження інсулінорезистентності зростала прямопропорційно ступеню ожиріння, про що свідчило зниження індексу Caro відносно IMT $(r=-0,95)$.

Крім цього, ще однією функцією лептину є захист периферійних тканин від ектопічного накопичення ліпідів завдяки антистеатогенному ефекту та регулюванню гомеостазу жирних кислот. У пацієнтів із різним ступенем ожиріння реєструється виражений

Таблиця 1. Порівняльна оцінка метаболічних порушень у пацієнтів з ожирінням та контрольної групи

\begin{tabular}{l|c|c|c}
\hline \multicolumn{1}{c|}{ Параметр } & Пацієнти 3 ожирінням $(\mathrm{n}=44)$ & Контрольна група $(\mathrm{n}=12)$ & $\mathrm{p}$ \\
\hline ІМТ, кг/м & $41,52 \pm 6,78$ & $20,89 \pm 2,06$ & 0,009 \\
\hline САТ, мм рт. ст. & $137,77 \pm 8,09$ & $120,17 \pm 3,48$ & 0,050 \\
\hline Глікемія, ммоль/л & $6,01 \pm 0,54$ & $5,58 \pm 0,37$ & 0,379 \\
\hline НbА1с, \% & $6,08 \pm 1,42$ & $5,43 \pm 0,25$ & 0,734 \\
\hline Інсулін, мкОД/мл & $24,56 \pm 4,56$ & $8,61 \pm 2,78$ & 0,004 \\
\hline Індекс Саго & 0,24 & 0,64 & 0,011 \\
\hline Грелін загальний & $747,54 \pm 338,65$ & $1380,48 \pm 146,34$ & 0,042 \\
\hline Лептин & $42,14 \pm 6,77$ & $5,02 \pm 3,79$ & 0,000014 \\
\hline Холестерин, ммоль/л & $6,21 \pm 1,43$ & $5,83 \pm 1,12$ & 0,835 \\
\hline ЛПНЩ, ммоль/л & $3,68 \pm 1,04$ & $3,47 \pm 1,09$ & 0,889 \\
\hline ЛПВЩ, ммоль/л & $1,18 \pm 1,02$ & $1,42 \pm 0,89$ & 0,859 \\
\hline Тригліцериди, ммоль/л & $1,76 \pm 0,64$ & $1,54 \pm 0,75$ & 0,824 \\
\hline Коесіцієнт атерогенності & $4,78 \pm 1,34$ & $3,21 \pm 1,27$ & 0,398 \\
\hline АлАТ & $36,89 \pm 1,67$ & $31,67 \pm 1,45$ & 0,021 \\
\hline АсАТ & $27,75 \pm 1,42$ & $23,56 \pm 1,21$ & 0,028 \\
\hline Креатинін, мкмоль/л & $76,50 \pm 8,04$ & $68,43 \pm 7,34$ & 0,461 \\
\hline
\end{tabular}


Таблиця 2. Порівняльна оцінка метаболічних порушень у пацієнтів з ожирінням різного ступеня

\begin{tabular}{|c|c|c|c|c|}
\hline Параметр & $\begin{array}{c}\text { Ожиріння I ст. } \\
(\mathrm{n}=8)\end{array}$ & $\begin{array}{c}\text { Ожиріння II ст. } \\
(\mathrm{n}=15)\end{array}$ & $\begin{array}{c}\text { Ожиріння III ст. } \\
(n=21)\end{array}$ & $\begin{array}{c}\text { Контрольна група } \\
(n=12)\end{array}$ \\
\hline $\mathrm{IMT}, \mathrm{Kг} / \mathrm{M}^{2}$ & $33,52 \pm 0,83$ & $37,68 \pm 1,46$ & $47,11 \pm 5,49$ & $20,89 \pm 2,06$ \\
\hline САТ, мм рт. ст. & $128,57 \pm 6,32$ & $137,53 \pm 6,81$ & $140,66 \pm 7,43$ & $120,17 \pm 3,48$ \\
\hline Глікемія, ммоль/л & $5,68 \pm 0,59$ & $6,01 \pm 0,54$ & $6,09 \pm 0,49$ & $5,58 \pm 0,37$ \\
\hline HbA1c, \% & $5,59 \pm 0,42$ & $6,22 \pm 1,33$ & $6,10 \pm 1,70$ & $5,43 \pm 0,25$ \\
\hline Інсулін, мкОД/мл & $21,44 \pm 3,89$ & $23,56 \pm 4,67$ & $27,89 \pm 5,21$ & $8,61 \pm 2,78$ \\
\hline Індекс Caro & 0,26 & 0,26 & 0,22 & 0,64 \\
\hline Грелін загальний & $1153,86 \pm 324,05$ & $733,29 \pm 274,58$ & $613,35 \pm 289,30$ & $1380,48 \pm 146,34$ \\
\hline Лептин & $18,05 \pm 8,87$ & $33,99 \pm 7,47$ & $55,24 \pm 6,19$ & $5,02 \pm 3,79$ \\
\hline Холестерин, ммоль/л & $6,40 \pm 1,24$ & $6,56 \pm 1,46$ & $6,78 \pm 1,78$ & $5,83 \pm 1,12$ \\
\hline ЛПНЩ, ммоль/л & $3,61 \pm 1,04$ & $3,79 \pm 1,02$ & $4,02 \pm 0,86$ & $3,47 \pm 1,09$ \\
\hline ЛПВЩ, ммоль/л & $1,23 \pm 1,04$ & $1,16 \pm 1,01$ & $1,04 \pm 0,98$ & $1,42 \pm 0,89$ \\
\hline Тригліцериди, ммоль/л & $1,71 \pm 0,38$ & $1,86 \pm 0,42$ & $1,95 \pm 0,74$ & $1,54 \pm 0,75$ \\
\hline Коефіцієнт атерогенності & $4,12 \pm 1,56$ & $4,47 \pm 1,18$ & $4,78 \pm 1,40$ & $3,21 \pm 1,27$ \\
\hline АлАТ & $35,67 \pm 1,15$ & $37,89 \pm 1,34$ & $40,11 \pm 1,23$ & $31,67 \pm 1,45$ \\
\hline AcAT & $27,01 \pm 1,78$ & $26,75 \pm 1,23$ & $28,85 \pm 1,12$ & $23,56 \pm 1,21$ \\
\hline Креатинін, мкмоль/л & $73,30 \pm 7,01$ & $74,50 \pm 7,67$ & $79,55 \pm 7,04$ & $68,43 \pm 7,34$ \\
\hline
\end{tabular}

дисбаланс тригліцеридів, холестерину, лПнщ і лПВщ, зумовлений лептинорезистентністю, що ініціює та підсилює патологічний атерогенез та атеросклероз. Кореляційний аналіз залежності рівня лептину та ліпідних орракцій встановив такі зв'язки: лПВщ $(r=-0,99)$, тригліцериди $(r=+0,97)$, коесріцієнт атерогенності $(r=+0,99)$.

За результатами дослідження встановлено, що концентрація греліну знижувалася при збільшенні ступеня ожиріння, досягаючи мінімальних значень при ожирінні III ст. порівняно з контрольною групою $(p=0,02)$. Глікемія між підгрупами значуще не змінювалася $(p=0,11)$. Проте встановлено достовірну залежність між IMT і величною САТ $(r=+0,88)$.

Оцінюючи отримані дані метаболічних порушень при розподілі пацієнтів за типом ожиріння, не встановлено достовірної різниці між досліджуваними показниками (табл. 3).

Таблиця 3. Порівняльна оцінка метаболічних порушень у пацієнтів з ожирінням різного типу

\begin{tabular}{|c|c|c|c|}
\hline Параметр & $\begin{array}{l}\text { Абдомінальний тип ожиріння } \\
(\mathrm{n}=16)\end{array}$ & $\begin{array}{c}\text { Глютеосреморальний тип } \\
\text { ожиріння }(\mathrm{n}=28)\end{array}$ & $\mathrm{p}$ \\
\hline $\mathrm{IMT}, \mathrm{k \Gamma} / \mathrm{M}^{2}$ & $41,52 \pm 6,78$ & $37,45 \pm 4,67$ & 0,623 \\
\hline САT, мм рт ст. & $137,77 \pm 8,09$ & $135,26 \pm 5,87$ & 0,802 \\
\hline Глікемія, ммоль/л & $6,01 \pm 0,54$ & $6,04 \pm 0,12$ & 0,957 \\
\hline $\mathrm{HbA1c}, \%$ & $6,08 \pm 1,42$ & $6,12 \pm 0,45$ & 0,978 \\
\hline Інсулін, мкОД/мл & $24,56 \pm 4,56$ & $18,23 \pm 3,80$ & 0,292 \\
\hline Індекс Caro & 0,24 & 0,33 & 0,888 \\
\hline Грелін загальний & $747,54 \pm 338,65$ & $843,32 \pm 287,64$ & 0,830 \\
\hline Лептин & $42,14 \pm 6,77$ & $39,86 \pm 7,89$ & 0,827 \\
\hline Холестерин, ммоль/л & $6,21 \pm 1,43$ & $6,63 \pm 1,72$ & 0,851 \\
\hline ЛПНЩ, ммоль/л & $3,68 \pm 1,04$ & $3,78 \pm 1,12$ & 0,948 \\
\hline ЛПВЩ, ммоль/л & $1,18 \pm 1,02$ & $1,13 \pm 0,92$ & 0,971 \\
\hline Тригліцериди, ммоль/л & $1,76 \pm 0,64$ & $1,81 \pm 0,72$ & 0,958 \\
\hline Коефріцієнт атерогенності & $4,23 \pm 1,34$ & $4,21 \pm 1,34$ & 0,991 \\
\hline АлАТ & $36,89 \pm 1,67$ & $40,55 \pm 1,23$ & 0,085 \\
\hline AcAT & $27,75 \pm 1,42$ & $27,43 \pm 1,15$ & 0,861 \\
\hline Креатинін, мкмоль/л & $76,50 \pm 8,04$ & $80,43 \pm 6,84$ & 0,711 \\
\hline
\end{tabular}

\section{вИСНОВкИ}

Результати проведеного аналізу підтвердили наявність дисбалансу орексигенних та аноресигенних гормонів у пацієнтів з ожирінням, при цьому відмі- чено прогресивне зростання концентрації лептину, інсуліну та зниження рівня греліну зі збільшенням ступеня ожиріння, що підтверджено відповідними кореляційними зв'язками. 


\section{СПИСОК ЛІТЕРАТУРИ}

1. Alvarez-Castro P. Ghrelin in obesity, physiological and pharmacological considerations / P. Alvarez-Castro, L. Pena, F. Cordido // Mini Reviews in Medicinal Chemistry. - 2013. - Vol. 13 (4). - P. 541-552.

2. Caro J. F. // J. Clin. Endocrinol. Metab. - 1991. Vol. 73, No. 4. - P. 691-695.

3. Chooi Y. C. The epidemiology of obesity / Y. C. Chooi, C. Ding, F. Magkos // Metabolism. -2019. - Vol. 92. - P. 6-10.

4. Ghrelin function in human obesity and type 2 diabetes: a concise review / R. Churm, J. S. Davies, J. W. Stephens, S. L. Prior // Obesity Reviews. - 2017. - Vol. 18 (2). P. $140-148$

5. Obesity-induced hypertension: role of sympathetic nervous system, leptin, and melanocortins / J. E. Hall, A. A. da Silva, J. J. M. do Carmo [et al.] // J. Biol. Chem. 2010. - Vol. 285. - P. 17271-17276

6. Kaur J. A comprehensive review on metabolic syndrome / J. Kaur // Cardiol. Res. Pract. - 2014. Vol. 2014. - P. 943162-943162.

\section{REFERENCES}

1. Alvarez-Castro P, Pena L, Cordido F. Ghrelin in obesity, physiological and pharmacological considerations. Mini Reviews in Medicinal Chemistry. 2013;13(4): 541-52.

2. Caro JF. J Clin Endocrinol Metab. 1999;73(4): 691-5.

3. Chooi YC, Ding C, Magkos F. The epidemiology of obesity. Metabolism. 2019;92: 6-10.

4. Churm R, Davies JS, Stephens JW, Prior SL. Ghrelin function in human obesity and type 2 diabetes: a concise review. Obesity Reviews. 2017;18(2): 140-8.

5. Hall JE, da Silva AA, do Carmo JM. Obesity-induced hypertension: role of sympathetic nervous system, leptin, and melanocortins. J Biol Chem. 2010;285: 17271-6.

6. Kaur JA. Comprehensive review on metabolic syndrome. Cardiol Res Pract. 2014; 943162.

7. Lilleness BM, Frishman $\mathbf{W H}$. Ghrelin and the cardiovascular system. Cardiology in Review. 2016;24(6): 288-97.
7. Lilleness B. M. Ghrelin and the cardiovascular system / B. M. Lilleness, W. H. Frishman // Cardiology in Review. 2016. - Vol. 24 (6). - P. 288-297.

8. Poetsch M. S. Role of leptin in cardiovascular diseases / M. S. Poetsch, A. Strano, K. Guan // Frontiers in Endocrinology. - 2020. - Vol. 11. - P. 354.

9. Rippe J. M. The epidemiology of adult obesity. In Obesity Prevention and Treatment / J. M. Rippe. - CRC Press. - P. 21-27.

10. Mechanisms and metabolic implications of regional differences among fat depots / T. Tchkonia, T. Thomou, Y. Zhu [et al.] // Cell Metab. - 2013. - Vol. 17. - P. 644-656.

11. Segregation of acute leptin and insulin effects in distinct populations of arcuate proopiomelanocortin neurons / K. W. Williams, L. O. Margatho, C. E. Lee [et al.] // J. Neurosci. - 2010. - Vol. 30. - P. 2472-2479.

12. Partial leptin reduction as an insulin sensitization and weight loss strategy / S. Zhao, Y. Zhu, R. D. Schultz [et al.] // Cell Metab. - 2019. - Vol. 30. - P. 706-719.

8. Poetsch MS, Strano A, Guan K. Role of leptin in cardiovascular diseases. Frontiers in Endocrinology. 2020;11: 354.

9. Rippe JM. The epidemiology of adult obesity. In Obesity Prevention and Treatment. CRC Press.

10. Tchkonia T, Thomou T, Zhu Y. Mechanisms and metabolic implications of regional differences among fat depots. Cell Metab. 2013;17: 644-56.

11. Williams KW, Margatho LO, Lee CE, Choi M, Lee S, Scott MM. Segregation of acute leptin and insulin effects in distinct populations of arcuate proopiomelanocortin neurons. J Neurosci. 2010;30: 2472-9.

12. Zhao S, Zhu Y, Schultz RD, Li N, He Z, Zhang Z. Partial leptin reduction as an insulin sensitization and weight loss strategy. Cell Metab. 2019;30: 706-19.

Отримано 04.10.21 